\begin{tabular}{|l|l|l|}
\hline \multicolumn{2}{|c|}{ PublisherInfo } \\
\hline \hline PublisherName & $:$ & BioMed Central \\
\hline \hline PublisherLocation & $:$ & London \\
\hline \hline PublisherImprintName & $:$ & BioMed Central \\
\hline \hline
\end{tabular}

\title{
Mammary gland cell proliferation and steroid receptor expression
}

\begin{tabular}{|l|l|l||}
\hline \multicolumn{2}{|c||}{ ArticleInfo } \\
\hline \hline ArticleID & $:$ & 3601 \\
\hline \hline ArticleDOI & $:$ & $10.1186 /$ bcr-1999-66582 \\
\hline \hline ArticleCitationID & $:$ & 66582 \\
\hline \hline ArticleSequenceNumber & $:$ & 21 \\
\hline \hline ArticleCategory & $:$ & Paper Report \\
\hline ArticleFirstPage & $:$ & 1 \\
\hline \hline ArticleLastPage & $:$ & 4 \\
\hline \hline & $:$ & RegistrationDate : 1999-6-1 \\
ArticleHistory & $:$ & OnlineDate $:$ 1999-6-1 \\
\hline \hline ArticleCopyright & $:$ & Current Science Ltd1999 \\
\hline \hline ArticleGrants & $:$ & \\
\hline \hline ArticleContext & $:$ & 1305811 \\
\hline \hline
\end{tabular}




\section{Keywords}

breast epithelium, cell proliferation, differentiation, estrogen receptors, progesterone receptors

\section{Introduction}

Ovarian steroid hormone-regulated cell proliferation is essential for the growth and development of the breast. The fact that the normal epithelium contains receptors for both estrogen and progesterone lends support to a receptor-mediated mechanism as the likely candidate for hormonal regulation of mammary gland development.

Previous studies by the authors of proliferative activity in the mammary epithelium of both rats and humans have demonstrated that cell division varies with the degree of structural differentiation of the mammary parenchyma. In humans, the highest level of cell division is observed in the undifferentiated lobules type 1 (lob1) present in the breast of young nulliparous females. The progressive differentiation of lob1 into lob2 and lob3, occurring under the hormonal influence of the menstrual cycle, and the full differentiation into lob4 during pregnancy, results in a concomitant reduction in the proliferative activity of the mammary epithelium. Interestingly, the authors have also shown that the content of estrogen receptor alpha (ER-alpha) and progesterone receptor $(\mathrm{PR})$ in the lobular structures of the breast is directly proportional to the rate of cell proliferation.

\section{Aims}

The present study was designed with the purpose of verifying the relationship between cells containing steroid hormone receptors and proliferating cells in the normal human and rat mammary glands. Specifically, the purpose was to test whether the cells expressing either ER-alpha or PR were those responding to hormones by cell division, thereby supporting the postulated receptor-mediated mechanism of cell growth stimulation.

\section{Comments}


The study confirms and extends recent research to show that steroid receptor containing cells and dividing cells constitute separate subpopulations of the human and rat mammary gland epithelium. These findings increase our understanding of steroid hormone control of mammary gland growth and development, and provide intriguing possibilities to explain the origins of ER-negative and ER-positive breast tumours.

\section{Methods}

Normal human breast tissues $(\mathrm{n}=12)$ were obtained from reduction mammoplasty specimens (age range 17-39 years). The tissues were formalin-fixed, paraffin-embedded and processed for light microscopy and double antibody immunocytochemical detection of cell proliferation (Ki67 antibody), ER-alpha and PR using commercially available antibodies. For double labelling, horse radish peroxidase and alkaline phosphatase detection systems were used.

Mammary gland tissue from 55 day old virgin Sprague Dawley rats was obtained $1 \mathrm{~h}$ after intraperitoneal injection of $3 \mathrm{H}$-thymidine. The tissue was formalin-fixed, paraffin-embedded and processed for light microscopy and immunocytochemical detection of ER-alpha and PR using commercially available antibodies followed by autoradiography.

\section{Results}

Human: The highest percentage of proliferating epithelial cells (Ki67 positive) was observed in lob1, reducing by 3 -fold and 10-fold in lob2 and lob3, respectively. The proliferating cells were almost exclusively luminal in location, while only occasional Ki67-positive cells were seen in the myoepithelium or the stroma. ER-alpha- and PR-positive cells were observed exclusively in the epithelium, with lob1 containing the highest proportion of positive cells, decreasing progressively in lob2 and lob3. Less than 1 in 15 Ki67-positive cells contained ER-alpha, while less than 1 in 50 Ki67-positive cells contained PR. When tissue sections were double labelled using antibodies to ERalpha and PR, almost all positive cells contained both receptors.

Rat:The mammary gland of young virgin rats was composed of ductal system ending in club-shaped terminal end buds (TEB) or primitive ductular, alveolar buds (AB) and lobular structures. 3H-thymidine was incorporated in $20 \%$ of cells in the TEB and was markedly lower in AB and lobules. ER-alpha and PR were detected in the epithelium lining TEB, AB and lobules, but not in the stroma. TEB contained the highest proportion of cells positive for ER-alpha and PR, and both were reduced in AB and lobules. In contrast to the human, the number of PR-positive cells was significantly higher than the number of ER-alpha-positive cells in the corresponding structures. Cells that had incorporated $3 \mathrm{H}$-thymidine had photographic silver grains overlying the nucleus, but were negative for both ER-alpha and PR. However, it was observed that $3 \mathrm{H}$-thymidine-labelled cells were juxtaposed to both ER-alpha and PR-positive cells. 


\section{Discussion}

Although the expression of steroid receptors in a separate subpopulation of cells to those that proliferate has been reported previously for human breast tissue, the present study extends those findings. Additional information on dividing cells and cells expressing steroid receptors in relation to the structural differentiation of the mammary gland is reported. Secondly, the relationship between these cells and structures of the rat mammary gland is described.

The results suggest that in both rat and human mammary epithelium, the control of cell proliferation by ovarian steroid hormones is likely to be indirect, possibly via secreted growth factors. The data may help to explain the origins of ER-negative and ER-positive breast tumours. The authors postulate that ER-negative tumours may arise from ER-negative dividing cells that are observed in the normal breast epithelium. In contrast, ER-positive tumours may arise from the small proportion of dividing cells that contain ER-alpha.

The findings also appear to explain in vitro studies of normal breast epithelial cells where expression of the ER has not been reported. It seems likely that when cells are placed in culture, only the ERnegative dividing cells can survive and therefore may constitute the breast epithelial stem cells and their progeny.

One caveat to this explanation is that it is unknown which breast cell subpopulation expresses the recently described novel form of the estrogen receptor, ER-beta.

\section{References}

1. Russo J, Ao X, Grill C, Russo IH: Pattern distribution of cells positive for estrogen receptor alpha and progesterone receptor in relation to proliferating cells in the mammary gland. Breast Cancer Res and Treat. 1999, 53: 217-227. 